\title{
@(๑)
}

Jurnal Bimbingan Konseling Indonesia is licensed under

A Creative Commons Attribution-Non Commercial 4.0 International License.

\section{EMOTIONAL ANALYSIS OF CHILDREN IN CLASS I PRIMARY SCHOOL}

\author{
J.Sunarti $^{1)}$, Iip Istirahayu ${ }^{2)}$, Slamat Fitriyadi ${ }^{3)}$ \\ ${ }^{1)}$ Prodi Bimbingan dan Konseling STKIP Singkawang, Singkawang, Indonesia \\ E-mail: tirasunarti@gmail.com \\ ${ }^{2)}$ Prodi Bimbingan dan Konseling STKIP Singkawang, Singkawang, Indonesia \\ E-mail: iip_istirahayu@yahoo.com \\ ${ }^{3)}$ Prodi Bimbingan dan Konseling STKIP Singkawang, Singkawang, Indonesia \\ Email: ahmadfitriyadi521@gmail.com
}

\begin{abstract}
This study aims to describe the emotional dynamics of first grade students at the beginning of the lesson and at the end of the lesson of one elementary school in Singkawang City and to analyse the factors causing the emotions of the first grade students at the beginning of the lesson and at the end of the lesson on one elementary school in Singkawang City. This type of research is qualitative research. Sources of data used are class I and Teacher homeroom I. Data collection techniques that researchers use is participatory observation in the process of learning in the classroom at the beginning and end of the lesson. Interview techniques in the form of structured interviews used to obtain information as complete as possible. Data collection techniques with documents in the form of writing and photos. Data Collecting Instrument used in this research are observation sheet, interview questionnaire and activity photo. The results explain the emotional dynamics in the first grade students of Brother Singkawang Elementary School at the beginning of the lesson is $100 \%$ happy. At the end of the hour $18 \%$ happy, $18 \%$ sad, and $63 \%$ angry. Factors causing emotions happy at the beginning of the lesson because it can meet friends, play and learn together. As for sad and angry emotions are not visible. At the end of the lesson there are happy emotions caused by content to play, full because they have eaten and ready to learn again and can answer teacher questions. The sad emotion at the end of the lesson is caused by still want to play, sick, hot weather, tired or tired and fighting. Furthermore, feelings of anger caused by a friend's fight and bullied, hot weather, angry due to the teacher warned and hyperactive.
\end{abstract}

Keywords: Analysis; Child Emotions

\section{INTRODUCTION}

Childhood is a very important life, experiences in childhood should be utilized as possible, child development is not only related to cognitive development, but also the emotional development of children. Children have a different uniqueness. So even in the emotions, there are children who are quiet, angry, patient, there are also children who have bad emotions but there are children who have good emotions.

To make it easier Santrock [1] defines emotion as a feeling that involves a mixture of physiological upheaval such as rapid pulse with behavior that looks like a smile or grimace.

Hurlock [2] says there are at least two reasons for controlling emotions in children. First, children begin to learn to control their emotions and succeed in doing so. The child will learn which emotional expressions are acceptable or unacceptable to his or her group. Thus, the child will only display the expression received by the group. Second, emotional expression patterns including anger have been learned by children since childhood. The earlier the child learns to control his emotions, the more easily the child controls his emotions in the future. 
The child will enter elementary school ranged in age between 6 to 12 years, at this age children experience a very drastic change both mental and physical. Children will further develop their thinking skills, acting and getting more complex social influences. During sitting in grade 1 to 3 elementary school, children begin to believe in themselves but also often low self-esteem. At this stage they start trying to prove that they are adults. They feel able to do their own work and have been able to be given a task. Children's concentration power begins to grow in grades 4 to 6 , they can spend more time on the task of their choice, and often they are happy to solve it. This stage also includes the growth of independent actions, cooperation with groups and acting in ways that are acceptable to their environment. They also began to care about the honest game. Children communicate their emotions through verbal, movement and body language, it can also be found in children in elementary school. Some children generally have different background problems related to the child's emotions.

Researchers conducted pre-research on Monday, October 10, 2016 with an observation of children's emotions conducted at one of the elementary schools in Singkawang city. Observations show that the emotional situation of children varies at the beginning of the lesson, most children seem happy but there are also which is sad, and the end of the lesson many children seem angry. From the results of these observations researchers interested in analyzing the emotions of children in grade 1 students in one elementary school in Singkawang. From the results of research conducted by researchers hope to strengthen the importance of paying attention to the emotions of children in elementary schools to further ensure the importance of Guidance and Counseling in Primary School.

\section{METHODS}

The research method that will be used by researcher in this research is phenomenological about the emotion of children with the symptoms of happy, sad and angry and the factors that can cause the emotion of children in grade 1 of Brother Singkawang Elementary School.

This study uses the type and design of qualitative research to analyze the emotions of children with symptoms of pleasure, sadness and anger and factors that can cause the emotion of children in grade 1 students Brother Singkawang Elementary.

Data collection techniques used by researchers is triangulation. Triangulation is defined as data collection techniques that combine from various data collection techniques. The researchers collected data using documentary techniques in the form of writing and photographs.

\section{RESULTS AND DISCUSSION}

A. Results

The first observations of the observations to the tenth can be more clearly seen in the table below.

TABLE I

DESCRIPTION OF THE CLASSROOM EMISSION I SD BRUDER SINGKAWANG AT LEARNING HOUR LESSON

\begin{tabular}{llccccc}
\hline \multirow{2}{*}{ No. } & \multirow{2}{*}{ Month } & Observation & \multicolumn{2}{c}{$\begin{array}{c}\text { Emotion picture at the } \\
\text { beginning of the lesson }\end{array}$} & $\begin{array}{c}\text { Number } \\
\text { of } \\
\text { Disciples } \\
\text { (people) }\end{array}$ \\
\hline 1. & October & I & 45 & 0 & 0 & 45 \\
2.. & & II & 44 & 0 & 0 & 44 \\
3. & November & III & 45 & 0 & 0 & 45 \\
4. & & IV & 45 & 0 & 0 & 45 \\
5. & & V & 45 & 0 & 0 & 45 \\
6. & & VI & 45 & 0 & 0 & 45 \\
7. & December & VII & 45 & 0 & 0 & 45 \\
8. & & VIII & 45 & 0 & 0 & 45 \\
9. & January & IX & 45 & 0 & 0 & 45 \\
10. & & X & 45 & 0 & 0 & 45 \\
& & & & & & \\
\hline
\end{tabular}

The emotional picture of the first grade students of Brother Singkawang Elementary School at the end of the lesson based on observations, interviews and documents between October 2016 to January 2017 can be seen in the table and graph below.

TABLE II

PURPOSE EMOTIONAL PICTURES

CLASS I SD BRUDER SINGKAWANG AT THE END OF HOURS OF STUDENTS

\begin{tabular}{|c|c|c|c|c|c|c|}
\hline \multirow{2}{*}{ No. } & \multirow{2}{*}{ Month } & \multirow{2}{*}{ Observation } & \multicolumn{3}{|c|}{$\begin{array}{c}\text { Emotional picture at the } \\
\text { end of the lesson }\end{array}$} & \multirow{2}{*}{$\begin{array}{c}\text { Number } \\
\text { of } \\
\text { Disciples } \\
\text { (people) }\end{array}$} \\
\hline & & & Happy & Sad & Angry & \\
\hline 1. & October & I & 8 & 12 & 25 & 45 \\
\hline $2 .$. & & II & 8 & 7 & 29 & 44 \\
\hline 3. & November & III & 8 & 8 & 29 & 45 \\
\hline 4. & & IV & 8 & 8 & 29 & 45 \\
\hline 5. & & V & 8 & 8 & 29 & 45 \\
\hline 6. & & VI & 10 & 7 & 28 & 45 \\
\hline 7. & December & VII & 8 & 8 & 29 & 45 \\
\hline 8. & & VIII & 8 & 8 & 29 & 45 \\
\hline 9. & January & IX & 8 & 7 & 30 & 45 \\
\hline 10. & & $\mathrm{X}$ & 8 & 8 & 29 & 45 \\
\hline
\end{tabular}




\section{B. Conclusion}

Factors that affect emotions in children, as in adults, emotional states vary from time to time, depending on factors such as health, time and day, and environmental influences. Rochman [3] The most important factors that affect children's emotions include fatigue, health, intelligence, social environment, family relations and aspiration levels.

Researchers conducted research on emotional analysis of children in grade 1 students at Brother Singkawang Element, which amounted to 45 children. The lesson starts at $07.00 \mathrm{am}$, breaks at $08.45 \mathrm{am}$, breaks at $09.00 \mathrm{am}$ and ends at $10.00 \mathrm{am}$. The condition of first grade students of Brother Singkawang Elementary School is 3 children with autism and 42 normal children. The policy to accept autistic students has been considered by the Bruder School Education Foundation on the record that some teachers are trained to manage students with autism.

Emotions in children are affected by physical conditions and emotional experiences in the context of their social life. Just like the emotional analysis that researchers did on 45 first-graders of Brother Singkawang Elementary School on the emotional dynamics of grade 1 students at the beginning of the lesson and at the end of the lesson and the emotional causes of the first-grade students at the beginning of the lesson and at the end of the lesson.

The factors that cause emotion at the end of the lesson, vary each student. On the cause of emotional factors happy to have an average of 8-10 students due to satisfied play, full because they have eaten, and ready to learn again and can answer teacher questions. Factors causing sad emotions on average there are 7-12 students due to factors cause still want to play, sick, hot weather, tired / tired and fighting.

Factors causing angry emotions found there are 25-30 students due to fighting and bullied friends, hot weather, angry because warned teachers and hyperactive.

\section{Conclusions And Suggestions}

\section{A. Conclusions}

The emotional dynamics of the first grade students of Brother Singkawang Elementary School at the beginning of the lesson is $100 \%$ happy. At the end of the hour $18 \%$ happy, $18 \%$ sad, and $63 \%$ angry.

Factors causing emotions happy at the beginning of the lesson because it can meet friends, play and learn together. As for sad and angry emotions are not visible. At the end of the lesson there are happy emotions caused by content to play, full because they have eaten and ready to learn again and can answer teacher questions.

The sad emotion at the end of the lesson is caused by still want to play, sick, hot weather, tired or tired and fighting. Furthermore, feelings of anger are caused because of fights and disrupted friends, hot weather, angry due to the teacher warned and hyperactive.

\section{B. Suggestions}

From the findings, the suggestion can be given to several parties, including:

1. Principal, from the results of research.

In order to determine the policy and recruit BK Teachers to solve students' emotional problems and to include teachers in trainings that can improve the quality of teachers in educating and teaching students in Brother Elementary School.

2. Teachers, should pay more attention to the child's emotions in the learning process.

3. The next researcher, as reference material and scientific study on the emotion of elementary school children in raising the relevant theme especially about the emotion of elementary school age children (elementary school), and can make further research with a wider sample and with different research methods.

\section{REFERENCES}

[1] Santrock, W John. (2002). Life Span Development, Perkembangan Masa Hidup. Jakarta : Erlangga.

[2] Jahya, Yudrik. (2011). Psikologi Perkembangan. Jakarta: Kencana Prenada Media Group.

[3] Natawidjaya, R. (1979). Psikologi Perkembangan. Jakarta: Departemen Pendidikan dan Kebudayaan. 